\title{
Insulin Secretory Status in Obese Female
}

\author{
Masuma Tasnim ${ }^{1}$, Qazi Shamima Akhter ${ }^{2}$, Salma Akhter ${ }^{3}$, Nasreen sultana lovely ${ }^{4}$, Khadiza \\ Begum $^{5}$, Susmita Sinha ${ }^{6}$
}

\begin{abstract}
Background: In obesity insulin hypersecretion is a key feature indicating the abnormal pancreatic beta cell function which is the fundamental defect in the development of NIDDM, hypertension and cardiovascular diseases. Objective: To assess the secretory status of insulin in adult obese female. Methods: The present study was a cross sectional analytical study and conducted in the Department of Physiology, Dhaka Medical College, Dhaka from July 2012 to June 2013. 50 obese female subjects of 20-40 years were included from Out-patient Department (Obesity clinic) of BIRDEM Hospital, Dhaka and by personal contact from different areas of Dhaka city. 50 age matched, healthy non-obese female subjects selected as controls . Fasting serum insulin level was measured by ELISA and fasting glucose level was measured by Glucose oxidase method. The insulin secretory status was calculated by HOMA-\%B using HOMA software. For statistical analysis unpaired Student's 't' test and Pearson's correlation coefficient ( $\mathrm{r}$ ) test were performed as applicable. Result: Mean fasting serum insulin and HOMA $\% \mathrm{~B}(\mathrm{P}<0.001)$ were higher in the obese than that non obese. Fasting serum insulin level and HOMA\%B showed significantly positive correlation with WHR. Conclusion: This study concludes that obese individual develops a state of insulin hypersecretion and hyperinsulinemia.
\end{abstract}

Key word: Obesity, HOMA-\%B, Hyperinsulinemia.

Bangladesh Soc Physiol. 2014, December; 9(2): 72-77 For Authors Affiliation, see end of text.

http://www.banglajol.info/index.php/JBSP

\section{Introduction}

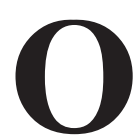

besity is abnormal or excessive fat accumulation that may impair health ${ }^{1}$. It is the sixth leading risk for global deaths. It kills more people than overweight ${ }^{2}$. The rise in prevalence of overweight and obesity is a negative consequence of increasing economic developments of many lower and middle-income countries in the Asia Pacific region ${ }^{3}$. South Asians are at higher risk than Caucasians for the development of obesity and obesity-related non-communicable diseases including insulin resistance, the metabolic syndrome, type 2 diabetes mellitus and coronary heart disease . $^{\text {. }}$

Received February 2014; Accepted September 2014
On the basis of the respective health-related risk factors, in Asian populations BMI e" $25.0 \mathrm{~kg} / \mathrm{m}^{2}$ is called obese 4,5 . The prevalence of obesity shows significant variation by racial and ethnic groups. However, obesity is present in $35.8 \%$ of adults living in the U.S. ${ }^{6}$ and $1.4 \%$ in Bangladesh ${ }^{7}$.

Obesity causes various metabolic changes such as increased blood glucose, increased hepatic very low density lipoprotein (VLDL) output, increased adipose tissue lipogenesis and VLDL uptake resulting from hyperinsulinemia ${ }^{8}$.

An obese person can sustain a normal plasma glucose concentration, but this requires an abnormally high circulating level of insulin. 
Chronic hyperinsulinemia has also been linked to complications similar to those seen in longstanding obesity ${ }^{9}$. The pathological changes associated with hyperinsulinemia are altered glucose metabolism, endothelial dysfunction, hypercoagulability, haemodynamic changes, chronic inflammation ${ }^{10}$, hypertension, decreased high-density lipoprotein cholesterol concentration, increased triglyceride concentration and non-insulin-dependent diabetes mellitus ${ }^{11}$.Insulin secretion of pancreatic â cell is estimated by HOMA method. In homeostasis model assessment (HOMA), insulin secretory capacity is expressed as $\mathrm{HOMA} \% \mathrm{~B}$, the higher the value of $\mathrm{HOMA} \% \mathrm{~B}$, the more the beta-cells capacity to secrete insulin ${ }^{12}$.

Obesity is characterized by elevated fasting plasma insulin and an increased insulin secretion in response to an oral glucose load ${ }^{13-14}$. Though obese individuals may develop different degrees of insulin secretory defect, but all of them may not have glucose intolerance and hyperglycemia 15 .

Some researchers did not find any relation with the body weight and plasma insulin level and HOMA $\% \mathrm{~B}^{16-17}$.

From the above studies it has been observed that, the result is conflicting. So the precise nature of the relationship between fasting serum insulin level and HOMA\%B in obesity is still obscure. Therefore this study has been designed to assess the insulin secretory status in adult obese female.

\section{Methods}

This is a cross sectional analytic study was conducted in Department of Physiology, Dhaka Medical College Dhaka from July 2012 to June 2013.Protocol of this study was approved by ethical review committee of Dhaka Medical College, Dhaka. A total number of 100 female subjects with the age ranging from 20-40 years were included in this study. Among them 50 apparently healthy obese female with BMI 25$39.9 \mathrm{Kg} / \mathrm{m}^{2}{ }^{4}$ and WHR $>0.85^{18}$ were included in study group and age and sex matched 50 healthy subjects with BMI $<25 \mathrm{Kg} / \mathrm{m}^{2}$ and WHR $<0.85$ were considered for comparison. They were selected from obesity clinic of BIRDEM, Dhaka and also by personal contact from different areas of Dhaka city. The objectives, nature, purpose and benefit of the study were explained to the subjects in details. Before taking blood, detailed medical history was taken and a careful physical examination was performed. All the subjects were excluded from diabetes mellitus, hypertension or any other endocrine diseases. Standing height, weight, waist and hip circumference were measured using soft non elastic measuring tape. Height measurement started from top of crown then to the back of the head, thoracic spine along the trunk, buttocks up to heels. Height, waist and hip circumference were recorded in centimeter $(\mathrm{cm})$. A standard weight measuring device was placed on a hard flat surface and checked for zero balance before measurement. Weight was recorded in kilogram $(\mathrm{kg})$. Body mass index (BMI) of the subjects were calculated using standard formula, BMI = Weight $(\mathrm{kg}) /$ Height (m) ${ }^{2}$. The waist circumference was taken in a standing position. It is the horizontal circumference between the lower border of the $12^{\text {th }}$ rib and the highest point of the iliac crest on mid-axillary line at the end of normal expiration. . It is the horizontal circumference at the highest point of buttock at the level of greater trochenter of head of femour. Waist hip ratio was calculated from standard formula, WHR: Waist circumference $(\mathrm{cm}) / \mathrm{Hip}$ circumference $(\mathrm{cm})$. All the information's were recorded on the structured data collection form. After overnight fasting, 5 $\mathrm{ml}$ of venous blood was collected at 8 am from every subject for estimation of serum glucose, serum insulin level. Glucose was measured by glucose oxidase method. Insulin was measured by ELISA method. The basal insulin secretion of pancreatic â cells was calculated by following equation, $\mathrm{HOMA} \% \mathrm{~B}=(20 \times$ Fasting serum insulin) / (Fasting blood glucose -3.5$)^{19}$. 
Data were expressed as mean \pm SD. For statistical analysis unpaired Student's 't' test and Pearson's correlation coefficient (r) test were done.

\section{Results}

The anthropometric characteristics were presented in Table I. BMI and WHR were significantly higher in obese female than healthy female. Systolic blood pressure, diastolic pressure and pulse were almost similar in obese and healthy female. But fasting serum insulin level and insulin secretion (HOMA\%B) were significantly higher in obese (Table II).

This study showed that $100 \%$ of control had normal insulin level (Figure 1).

In this study, $8.0 \%$ obese subject had hyperinsulinemia (Figure 2), cut up point for hyperinsulinemia was $<27 \mu \mathrm{IU} / \mathrm{ml}^{20}$.

Correlation analysis showed significant positive correlation between fasting serum insulin and WHR in obese (Figure 4).

HOMA\%B was positively correlated with BMI and WHR in obese but it was not significantly positive (Figure 6, 5)

Table I: General characteristics in both groups $(n=50)$

\begin{tabular}{lcc}
\hline Parameters & $\begin{array}{c}\text { Non-obese } \\
(\mathrm{n}=50)\end{array}$ & $\begin{array}{c}\text { Obese female } \\
(\mathrm{n}=50)\end{array}$ \\
\hline Age $(\mathrm{yrs})$ & $27.64 \pm 4.72$ & $28.02 \pm 5.78$ \\
& $(20-38)$ & $(20-38)$ \\
BMI $\left(\mathrm{Kg} / \mathrm{m}^{2}\right)$ & $22.18 \pm 2.00$ & $30.85 \pm 3.65^{*}$ \\
& $(17.90-24.70)$ & $(25.0-39.9)$ \\
WHR & $0.78 \pm 0.03$ & $0.86 \pm 0.05^{*}$ \\
& $(0.68-0.84)$ & $(0.78-0.98)$ \\
SBP(mmHg) & $111.00 \pm 7.35$ & $110.30 \pm 6.88$ \\
& $(100-120)$ & $(100-120)$ \\
DBP(mmHg) & $68.40 \pm 6.81$ & $67.70 \pm 7.23$ \\
& $(60-80)$ & $(60-80)$ \\
Pulse(beat/min $)$ & $76.12 \pm 8.255$ & $78.9 \pm 8.83$ \\
& $(65-90)$ & $(65-90)$ \\
\hline
\end{tabular}

Data were expressed in mean \pm SD. Unpaired student's ' $\mathrm{t}$ ' test analyzed statistical significance. $\mathrm{BMI}=\mathrm{Body}$ mass index, $\mathrm{WHR}=$ Waist hip ratio, $\mathrm{SBP}=$ Systolic blood pressure, $\mathrm{DBP}=$ Diastolic blood pressure. ${ }^{*} \mathrm{P}<0.001$
Table II: Fasting serum glucose, fasting serum insulin and insulin secretory status (HOMA \% B) in both groups $(n=100)$

\begin{tabular}{lcc}
\hline Parameters & $\begin{array}{c}\text { Non-obese } \\
(\mathrm{n}=50)\end{array}$ & $\begin{array}{c}\text { Obese female } \\
(\mathrm{n}=50)\end{array}$ \\
\hline Fasting serum & $4.79 \pm 0.53$ & $5.79 \pm 0.41$ \\
glucose $(\mathrm{mmol} / \mathrm{l})$ & $(3.60-5.80)$ & $(5.10-6.80)$ \\
Fasting serum & $10.17 \pm 1.92$ & $19.38 \pm 4.78^{*}$ \\
insulin $(\mu \mathrm{IU} / \mathrm{ml})$ & $(6.34-12.96)$ & $(11.0-33.48)$ \\
HOMA \% B & $136.09 \pm 21.53$ & $152.27 \pm 14.31^{*}$ \\
& $(62.90-189.80)$ & $(121.40-178.60)$ \\
\hline
\end{tabular}

Data were expressed in mean \pm SD. Unpaired student's ' $\mathrm{t}$ ' test analyzed statistical significance HOMA= Homeostatic model assessment. ${ }^{*}=\mathrm{P}<0.001$

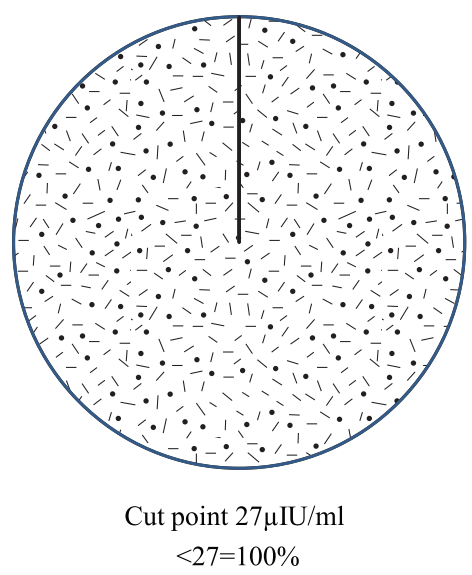

Figure 1: Frequency distribution of fasting serum insulin level in non obese $(n=50)$

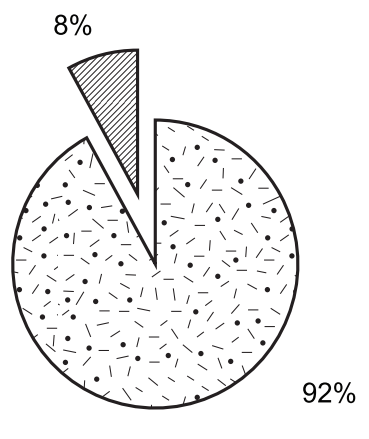

Cut point $27 \mu \mathrm{IU} / \mathrm{ml}$

Figure 2: Frequency distribution of hyperinsulinemia in obese $(\mathrm{n}=50)$ 


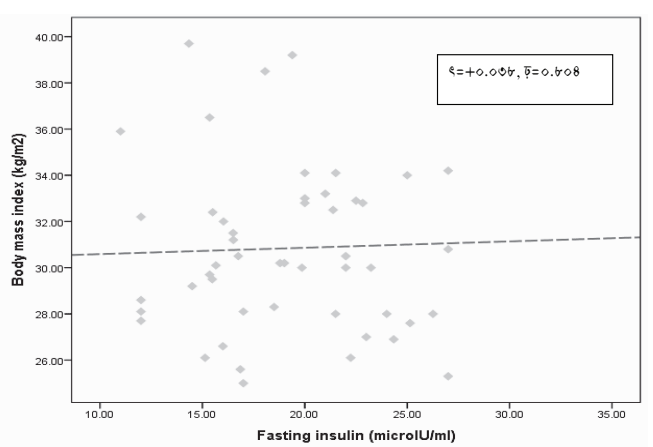

Figure 3: Correlation between BMI and fasting serum insulin level in obese $(n=50)$

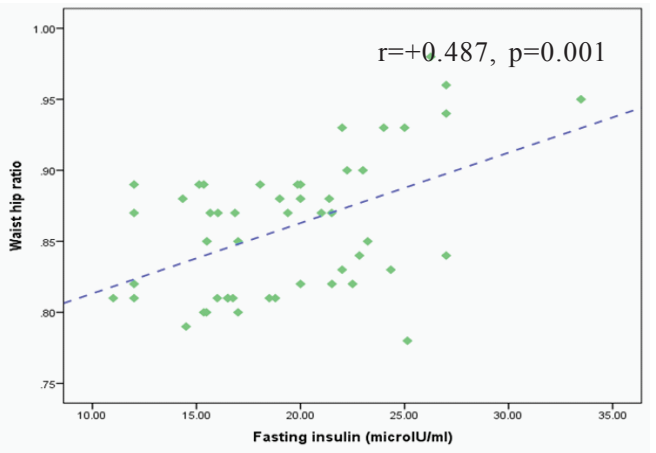

Figure 4: Correlation between waist hip ratio and fasting serum insulin level in obese. Strong positive relationship between obesity and fasting insulin level is showing increasing secretory response of $b$ cell to obesity.

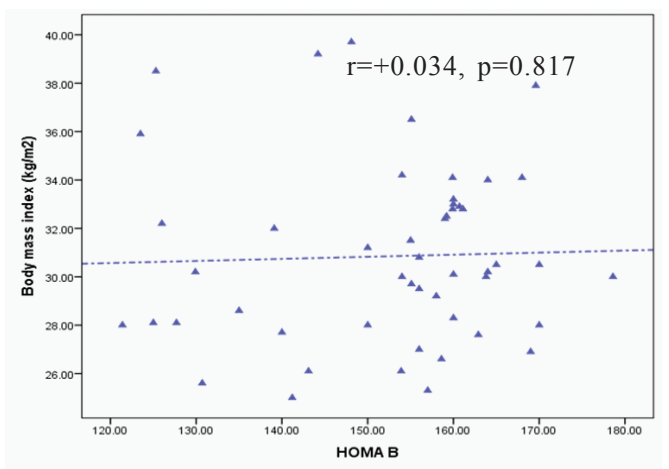

Figure 5: Correlation between $\mathrm{BMI}$ and HOMA $\%$ B in obese $(n=50)$.

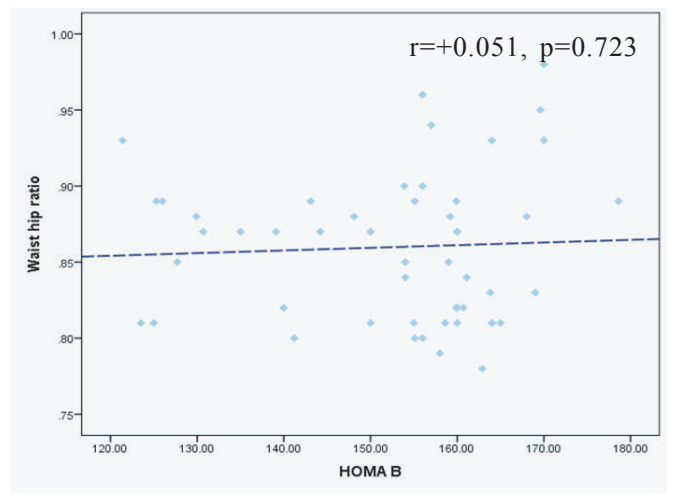

Figure 6: Correlation between waist hip ratio and HOMA $\%$ B in obese $(n=50)$.

\section{Discussion}

The present study observed the insulin secretory capacity by â cells and blood insulin level in healthy obese. In this study, $8 \%$ of obese female have hyperinsulinemia. In addition, correlation analysis showed strong positive relationship between â cells insulin secretory capacity and insulin level in obese patient which reflects the increased secretory response of â cells to obesity. This finding of increased insulin secretory state of â cells in obese subject is similar to other researcher ${ }^{16-17}$.

Elevated serum insulin level and increased insulin secretion by â cells supported by significantly higher HOMA\%B indicate that there may be link between this increased rate of secretion and hyperinsulinemia in obese person.

It has been suggested from research review that type-II diabetes mellitus usually in obese is associated with hyperinsulinemia and elevated blood glucose level. There is evidence that, in an obese person, tissue become resistance to the insulin action causing elevated blood sugar. In addition literature reviews revealed the role of elevated fatty acid for development of tissue insulin resistance. In response, pancreatic â cells increase the insulin secretion by feedback mechanism. High level of free fatty acids in obesity stimulates further insulin release from beta cells. As a result hyperinsulinemia occurs ${ }^{21-22}$. 
A mechanism at cellular level for insulin resistance proposed that, intracellular accumulation of free fatty acid metabolites such as fatty acyl CoA, diacylglycerol and ceramides in muscle and liver activate protein kinase $\mathrm{C}$ causing phosphorylation of serine/threonine residue of IRS-1/IRS-2 and also decreases tyrosine phosphorylation of IRS-1/IRS-2 23 . The serine phosphorylated form of IRS protein fails to activate phosphatidyleinositol 3 kinase (PI 3) which is associated with GLUT-4 activity. As a result, decrease translocation of GLUT -4 in cell membrane yield insulin signaling defect and insulin resistance ${ }^{10}$.

In the present study though obese subjects are not diabetic, still they developed hyperinsulinemia and showed increased secretory capacity of ${ }^{2}$ cell. Though these subjects have not yet developed diabetes still this pathological feature may be accountable to the same mechanism. But as the tissue resistance and tissue sensitivity to insulin has not been investigated in this article this finding of this study indicates there may be strong relationship between increased $^{2}$ cell sensitivity, hyperinsulinemia and obesity.

As it is well recognized fact that development of diabetes mellitus in obesity is high risk for cardiovascular diseases, the present finding shows the evidence even before the actual development of diabetes mellitus, obesity induced altered ${ }^{2}$ cell function causing hyperinsulinemia.

Finally, from the limitation of studying other factors the cause of increased ${ }^{2}$ cell sensitivity in obese subject is not clear, further research is needed to explore the cause of ${ }^{2}$ cell sensitivity in obesity.

\section{Conclusion}

From the result of the study it can be concluded, obesity may induce ${ }^{2}$ cell hypersensitivity leading to insulin hypersecretion and hyperinsulinemia.

\section{Acknowledgement}

The author acknowledge Department of Physiology and Molecular Biology, BIRDEM, Dhaka for providing software (HOMA-CIGMA software) support for the calculation of HOMA\%B.

\section{Authors affiliations}

1. * Masuma Tasnim, Assistant professor, Department of Physiology, Ad-din Women's Medical college, Dhaka. Email: tasnim_masuma@yahoo.com

2. Qazi Shamima Akhter, Professor, Head, Department of Physiology, Dhaka Medical College, Dhaka. Email:

3. Salma Akhter, Associate professor, Department of Physiology, Ad-din Women's Medical college, Dhaka. Email:

4. Nasreen Sultana lovely, Assistant professor, Department of Physiology, Ad-din Women's Medical college, Dhaka. Email:nasreenmasud 7@gmail.com.

5. Khadiza Begum, Assistant professor, Department of Physiology, Ad-din Women's Medical college, Dhaka. Email:begumkhadiza15@yahoo.com

6. Susmita Sinha, Assistant professor, Department of Physiology, Eastern Medical college, Comilla. Email:scobidu9999@yahoo.com.

*For correspondence

\section{References}

1. Kumar V, Abbas AK, Fausto N \& Astro JC. Robbins \& Cotran Pathological Basis of Disease. $8^{\text {th }}$ ed. Philadelphia: Elsevier Inc; 2010.

2. Haslam DW, James WP. Obesity. Lancet 2005; 366: 1197-209.

3. Lee CMY, Martiniuk ALC, Woodward M, Feigin $\mathrm{V}$, Gu DF, Jamrozik K et. al. The burden of overweight and obesity in the Asia-Pacific region. Obes rev 2007;8: 191-6

4. Misra A, Khurana L .Obesity-related noncommunicable diseases: South Asians vs White Caucasians. Intern J Obes 2011; 35: 167-87.

5. Hubbard VS .Defining overweight and obesity: what are the issues?. Am J Clin Nutr 2000; 72: 1067-8.

6. Flegal KM, Carroll MD, Kit BK, Ogden CL. Prevalence of obesity and trends in the distribution of body mass index among US adults, 1999-2010. JAMA 2012; 307(5): 491-97.

7. Balarajan Y, Villamor E .Nationally representative surveys show recent increases in the prevalence of overweight and obesity among women of reproductive age in Bangladesh, Nepal and India. J Nutr 2009; 139: 2139-44. 
8. Jeanrenaud B .Hyperinsulinemia in obesity syndromes: Its metabolic consequences and possible etiology. Metabolism 1978; 27(12):1881-92.

9. Garcia-webb P .Insulin resistance-a risk factor for coronary heart disease?. Scand J Clin Lab Invest 1983; 43: 677-85.

10. Mercurio V, Carlomagno G, Fazio V, Fazio, S. Insulin resistance: Is it time for primary prevention? World J Cardiol 2012; 4(1):

11. Haffner SM, Howard G, Mayer E, Bergman RN, Savage PJ, Rewers $M$ et. al. Insulin sensitivity and acute insulin response in African-Americans, nonHispanic whites and Hispanics with NIDDM. Diabetes 1992; 46:63-9.

12. Al-Mahmood AK, Ismail AA, Rashid FA, Bebakar WMW. Insulin sensitivity and secretory status of a healthy Malay population. Malay J Med Sci 2006; 13(2): 37-44.

13. Kopelman $\mathrm{P}$.Health risks associated with overweight and obesity. Obes Rev 2007; 8 (Suppl. $1)$; $13-7$.

14. Jones RCNO, Abbasi F, Carantoni M, Polonsky KS, Gerald M. Roles of insulin resistance and obesity in regulation of plasma insulin concentrations. Am J Physiol Endocrinol Metab 2000; 278: E501-08.

15. Steinberger J, Daniels SR .Obesity, insulin resistance, diabetes and cardiovascular risk in children. Circulation 2003; 107: 1448-53.
16. Reaven GM .Role of insulin resistance in human disease. Diabetes 1988; 37: 1595-607.

17. Levine ME, Crimmins EM. The impact of insulin resistance and inflammation on the association between sarcopenic obesity and physical functioning. Obesity 2012;20: 2101-06.

18. Deepa S, Shanthirani CS, Premalatha G, Sastry NG , Mohan V. Prevalence of insulin resistance syndrome in a selected south Indian populationThe Chennai urban population study-7. Indian J Med Res 2002: 115: 118-27.

19. Singh B, Saxena A. Surrogate markers of insulin resistance: A review. World J Diabetes 2010;15( 1): 36-47.

20. Burris CA, Ashwood ER, Burns DE. Tietz Textbook of Clinical Chemistry \& Molecular Diagnostics.4 ${ }^{\text {ed }}$ .St. Louis: Elsevier Saunders; 2006.

21. Ludvik B, Nolan JJ, Baloga J, Sacks D, Olefsky J. Effect of obesity on insulin resistance in normal subjects and patients with NIDDM. Diabetes 1995; 44: 1121-25.

22. Shanik MH, Xu Y, Krha J, Danker R, Zick Y, Roth $\mathrm{J}$.Insulin resistance and hyperinsulinemia. Diabet Care 2008; 31(Suppl.2): S262-68.

23. Shulman GI .Cellular mechanisms of insulin resistance. J Clin Invest 2000; 106(2). 